\title{
Hugh Miller: fossils, landscape and literary geology
}

\author{
Simon J. Knell ${ }^{1}$ \& Michael A. Taylor ${ }^{2}$
}

KNELL, S. J. \& TAYLOR, M. A. 2006. Hugh Miller: fossils, landscape and literary geology. Proceedings of the Geologists' Association, 117, 85-98. The bicentenary of the birth of Hugh Miller (1802-1856) in Cromarty (in northern Scotland) has enabled a reappraisal of this fine spare-time geologist, in turn stonemason and banker, and eventually Edinburgh newspaper editor. In Cromarty he had the usual advantages and limitations of a local collector far from metropolitan centres. But Miller was different from other collectors: he was author of classic books such as The Old Red Sandstone, making famous the Old Red Sandstone fishes and Jurassic marine fossils of the area around Cromarty. Miller's ironically titled autobiography My Schools and Schoolmasters recommended geology as an improving recreation. His writings are suffused with the thrill of discovery and the wonder and beauty of fossils, inspiring future geologists such as John Muir (1838-1914), pioneer of environmental conservation, and George Jennings Hinde (1839-1918), microfossil researcher.

In his often autobiographical writings Miller made geology an integral part of the world as he saw it: he was not 'just' a 'popularizer', but (as he always wanted) a literary man in the all-encompassing Victorian manner. Geology merged with local history and folklore - all 'libraries' of the past. But his writings remain rooted in insightful observation - as scientist and poet - of specimen and scenery, from microscope slide to landscape, and in careful reconstruction, for instance, of fossil animals from fragmentary remains.

When Miller dealt with wider issues of God in creation and the truths of geology, he deployed his fossils, as in Footprints of the Creator (1849) which attacked the reheated Lamarckian evolutionism of Vestiges of the Natural History of Creation (1844). But, contrary to the common misconception that he was driven to suicide by a conflict between science and religion, Miller simply saw these as different facets of the same truth. Indeed, he notably defended geology against religious literalists.

Miller's fossil collection is now mostly in the National Museums of Scotland, Edinburgh, with some specimens in the new Hugh Miller museum, Cromarty, which derives from that founded by his son, also called Hugh (1850-1896), a professional geologist with the Geological Survey.

This appraisal reveals further depths to Hugh Miller's appreciation of geological specimens, and to the significance of his surviving collection. Miller's relationship with the material world of objects shows remarkable consistency and an unwillingness to compartmentalize: Miller's fossils exemplify the deep continuity of his world.

Key words: Hugh Miller, fossil collecting, history of geology, history of vertebrate paleontology, literary geology, museums, Old Red sandstone, Jurassic, Devonian

${ }^{1}$ Department of Museum Studies, University of Leicester, 105 Princess Road East, Leicester LE1 7LG, UK

${ }^{2}$ National Museums of Scotland, Chambers Street, Edinburgh EH1 1JF, Scotland, UK

\section{INTRODUCTION}

... I saw a labourer at work with a pick-axe, in a little craggy ravine, about a hundred yards to the left of the path, and two gentlemen standing

This paper is a revised version of one originally presented at the Hugh Miller Bicentenary Conference, organised by the Cromarty Arts Trust at Cromarty in October 2002 (Borley 2003) and is an invited addition to the papers arising from the joint meeting of the Geological Society of London History of Geology Group and the Geologists' Association, The Amateur in British Geology, held at The Geological Society, Burlington House, London, 14-15 March, 2002. beside him. I paused for a moment, to ascertain whether the latter were not brother-workers in the geologic field. 'Hilloa! - here,' shouted out the stouter of the two gentlemen, as if, by some clairvoyant faculty, he had dived into my secret thought; 'come here.' I went down into the ravine, and found the labourer engaged in disinterring ichthyolitic nodules out of a bed of gray stratified clay ... a heap of freshly-broken nodules, speckled with the organic remains of the Lower Old Red Sandstone, - chiefly occipital plates and scales, lay beside him. 'Know you aught of these?['] said the stouter gentleman, pointing to the heap. 'A 
little,' I replied; 'but your specimens are none of the finest. Here, however, is a dorsal plate of Coccosteus; and here a scattered group of scales of Osteolepis; and here the occipital plates of Cheirolepis Cummingiar; and here the spine of the anterior dorsal of Diplacanthus Striatus.' My reading of the fossils was at once recognized, like the mystic sign of the freemason, as establishing for me a place among the geologic brotherhood; and the stout gentleman producing a spirit-flask and a glass, I pledged him and his companion in a bumper. 'Was I not sure?' he said, addressing his friend: 'I knew by the cut of his jib, notwithstanding his shepherd's plaid, that he was a wanderer of the scientific cast.' We discussed the peculiarities of the deposit ... I showed the younger of the two geologists my mode of breaking open an ichthyolitic nodule, so as to secure the best possible section of the fish. 'Ah,' he said, as he marked a style of handling the hammer which, save for the fifteen years' previous practice of the operative mason, would be perhaps less complete, - 'Ah, you must have broken open a great many.' His own knowledge of the formation and its ichthyolites had been chiefly derived, he added, from a certain little treatise on the 'Old Red Sandstone', rather popular than scientific, which he named. I of course claimed no acquaintance with the work; and the conversation went on [From The Cruise of the Betsey, with, Rambles of a Geologist (Miller, 1858b, pp. 240-241).]

The plaid-wearing former stonemason was, of course, Hugh Miller (1802-1856; Figs 1, 2), author of the classic book The Old Red Sandstone, an exquisite study of one small corner of Scotland which is to Scottish geology as The Natural History of Selborne is to the English countryside. Miller was certainly a very good geologist, as an observer in the field or of the minute detail of his fossils, but he published rather little formal academic geology, contrary to what one might imagine from his reputation. Therefore, how one regards Miller's actual contribution to geology - or rather palaeontology - is critically dependent on how one defines science (Miller's contribution is notably discussed by Oldroyd, 1996; see also Andrews, 1982; Waterston, 2002a, b; Hudson, 2003; Janvier, 2003; Morrison-Low \& Nuttall, 2003; Secord, 2003; Taylor, 2003; Torrens, 2003; Trewin, 2003; Anderson, 2005). Indeed, from the point of view of the metropolitan élite of the Geological Society of London, Miller would simply have been yet another talented provincial collector, if one who was rather good at popularizing the science (Knell, 2000, pp. 148-149).

Miller did his collecting in his spare time, for he was primarily busy with other occupations. First a stonemason, then a bank accountant, he became the editor of an important, and politically independent, Scottish newspaper, The Witness, where he played a major part in the disputes over control of the Church of Scotland;

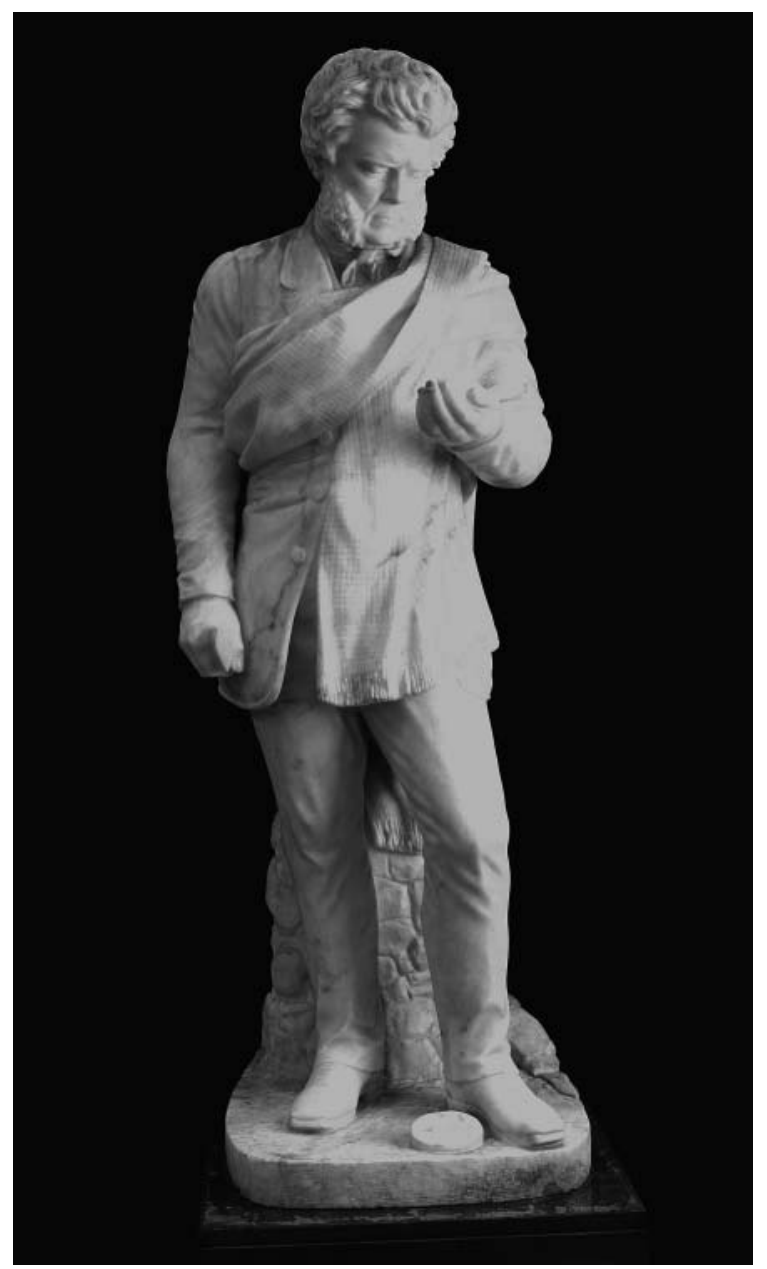

Fig. 1. Statue of Hugh Miller in his characteristic outdoors Lowlander Scots dress by Amelia Paton Hill, exhibited at the Royal Scottish Academy, 1869 (title given as 'The late $\mathrm{Mr}$ Hugh Miller, author of The Old Red Sandstone' in Baile de Laperrière, 1991, p. 288). It must surely portray Miller discovering his eponymous Pterichthys milleri at the Old Red Sandstone fish locality on the beach at Cromarty; the split nodule with the fossil, half in hand and half at feet, is typical of the Cromarty site, as is the coarse conglomerate boulder 'supporting' him. (There is a different statue, by Handyside Ritchie, on the monument at Cromarty.) Paton was the wife of David Octavius Hill who with his partner Robert Adamson created the deservedly famous 'calotype' photos of Hugh Miller and many of their contemporaries. Miller also features prominently in Hill and Paton's famous 'Disruption Painting' of the formation of the Free Church in 1843, The Signing of the Deed of Demission (Stevenson, 2002). Statue NMS.A.1887.735, photograph by NMS Photography Section, copyright The Trustees of the National Museums of Scotland.

Miller supported the Church's independence and had much to do with the founding of the Free Church of Scotland in 1843. More generally he supported the 


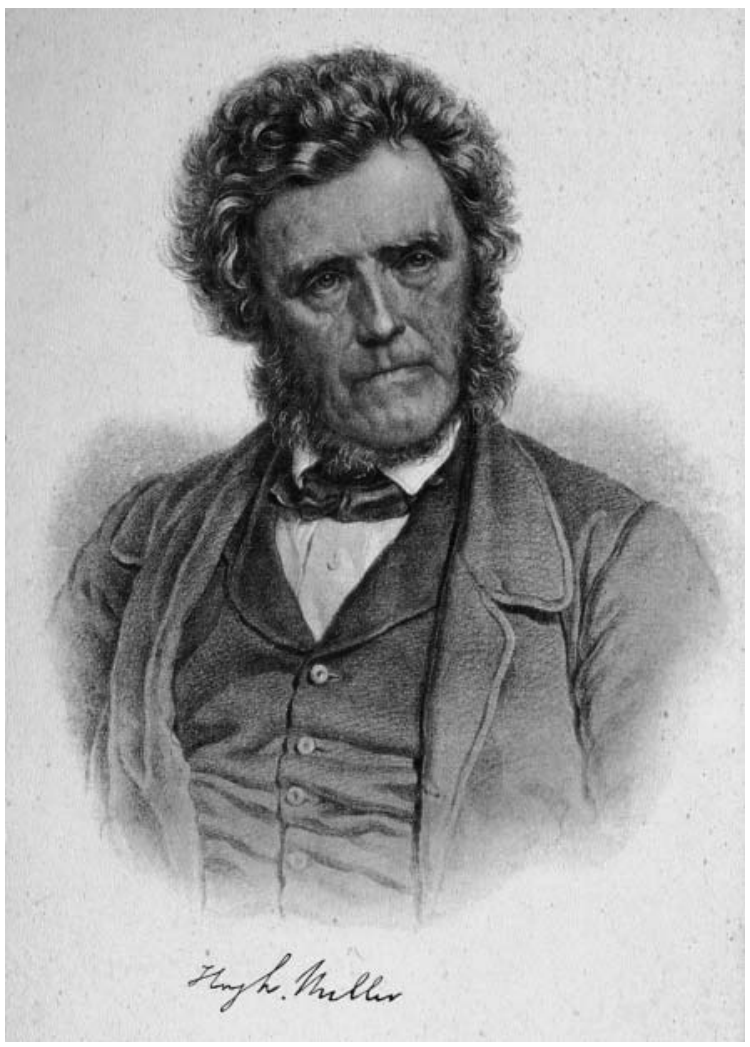

Fig. 2. Hugh Miller: frontispiece of Selections from the Writings of Hugh Miller (Mackenzie, 1908). Photograph by Suzie Stevenson, copyright The Trustees of the National Museums of Scotland.

traditional role of the Kirk in everyday life, although he was never an uncritical mouthpiece of the Kirk's managers; for instance, he favoured care of the deserving poor, old and infirm through the Kirk in the traditional manner, but - contrary to what those unfamiliar with Miller might expect - he was in favour of a State-controlled and non-sectarian educational system, if one still based on Presbyterian Christian mores (Robb, 1996).

But Miller's bookish childhood and varied occupations made him a very unusual part-time geologist. His journalistic competence, superb literary skills, lively interest in many subjects and Presbyterian credentials made him an important advocate for geology, especially amongst people who read his books for other reasons (O'Connor, 2003a, b; Secord, 2003). At the same time he was an advocate, and indeed a living exemplar, of education and self-help in the best Victorian manner (which was in any case something of an old Scots tradition). In The Old Red Sandstone, and in his wonderfully ironically titled autobiography $M y$ Schools and Schoolmasters, Miller recommended geology as an excellent example of the kind of improving and constructive recreation which anyone at any level of society could and should take up. This was, moreover, at a time when geology and biology posed important questions about the literal truth of the Bible, the nature of divine creation and the origin of humanity. Indeed, contrary to the common modern misconception, Miller was no literalist interpreter of the Bible when it came to geology.

Miller espoused his unique brand of 'literary geology' amongst the many kinds of geologist then practising the new science (Knell, 2000), from the widely denigrated Biblical literalists and the dilettante gentlemen collectors to the rising professionals to be found in the museum, university and geological survey. His penetrating insight and apt comments still delight the reader today, even on such unpromising themes as failed coal mines (Torrens, 2003), or when he provides the historian with a stylish mot juste, as when considering the relationship of geology and archaeology (Torrens, 1998).

It is never easy to measure someone's impact on the wider public, outside the formal debates and publications of learned societies, especially as it depends so much on the individual reader, as shown by Secord (2000) for Miller's opponent, Robert Chambers, the evolutionist. Miller was certainly no mere popularizer; rather, he was a literary man in the wide, allencompassing Victorian sense (O'Connor, 2003a, b) and richly aware of the Scottish literary tradition (Robertson, 2002). Yet it is known that Miller turned some - and perhaps many - individuals, often in isolated communities, towards geology. Oldroyd (1996) rightly claims that, in a sense, Miller's greatest find was Archibald Geikie (1835-1924), often regarded as the science's figurehead in the late nineteenth century, whom Miller had personally encouraged to take up geology. There was seemingly a generation whose imagination Miller's elegant prose captured for geology. John Muir (1838-1914), the émigré ScottishAmerican pioneer of environmental conservation, read Miller as a young man and named an Alaskan glacier after Miller (Taylor, 2002a; Lowenthal, 2003). George Jennings Hinde (1839-1918), a pioneer of micropalaeontology and its use in stratigraphy, came to geology as a result of reading Miller's works (Woodward, 1918).

Miller managed his working life carefully to give himself opportunity to write on his favourite subject. He had long held literary desires and, consequently, the geology he produced was unlike that of his contemporaries. He had geological friends (Collie, 2003) and he did not disdain organized societies - he was active in the Royal Physical Society of Edinburgh, one of the obvious local venues for geology (Taylor 2002b, c) - but he was a long way from the metropolitan savants of the Geological Society of London, in more senses than one.

Miller has never, in fact, been quite forgotten - his memory has been preserved, for instance by geologists and, also, especially, by the folk of Miller's birthplace, 
the burgh of Cromarty on the Moray Firth in the far north of Scotland, whose local library is named the Hugh Miller Institute. The National Trust for Scotland holds his preserved birthplace cottage and, in April 2004, it opened a new museum about him in Miller House next door (Gostwick, 2004). Meanwhile, Miller's statue on the monument above the town looks out to the site of his classic discoveries in the Old Red Sandstone.

However, there has recently been more interest in Scottish history and culture and, independently, also in pre-Darwinian science and thought. This has encouraged wider interest in and a reassessment of Miller, especially after the bicentenary of his birth in 2002 and the associated events co-ordinated by the Cromarty Arts Trust, notably the meetings now published as Borley $(2002,2003)$.

Repository abbreviation. NMS, National Museums of Scotland, Chambers Street, Edinburgh EH1 1JF, Scotland, UK.

\section{CONSIDERING THE FOSSIL DISCOVERER AND COLLECTOR}

This paper is concerned with Hugh Miller's geological collection: the fossils he discovered, how he found them, what they meant to him and how he used them. We consider Miller's usage of fossils as objects of the material culture of his day and, by taking that point of view, we are explicitly including science in that culture, with sometimes surprising results. This territory was explored in some depth by Paradis (1996) in Shortland (1996). Miller's autobiographical mode of writing means that our paper also overlaps, for instance, with Alston's interest in Miller's local context in Cromarty and Vincent's work on his self-cultivation and development (Alston, 1996; Vincent, 1996). This paper does not discuss Miller's important contribution, partly based on his fossil collection, to the progress of formal scientific thought, as this has been well reviewed by David Oldroyd and others (Oldroyd, 1996).

Hugh Miller poses an obvious historiographic problem, a difficulty in the practice of history, partly because of the breadth of his interests which he brought before the public eye in his writings. As a consequence, different commentators have read Miller quite differently. Of course, many of his contemporaries also had diverse interests (Knell, 2000). For example, George Cumberland of Bristol has been viewed quite separately as an artist's friend, antiquarian and geologist, while the Marquis of Northampton has been seen as politician, tourist, landowner, collector and patron of science. However, neither made much of a literary mark. Few nineteenth-century geologists were as single-minded as histories often seem to imply. But few of Miller's geological contemporaries developed a public profile in such an array of apparently disparate fields. In Miller's case these fields included religion, politics, folklore, geology and journalism. Fewer still committed their views to paper and even fewer wrote themselves into their work as overtly as Miller did. These issues pose challenges to our interpretation of Miller's intent, particularly given the necessity of often having to rely upon his selfportrayal. It is a portrayal laced with the high morality of his tales and a liberal application of his own hindsight and yet also infused with a dry wit and a subtle irony that modern readers sometimes miss (with the inevitable consequences for their comprehension).

A second historiographic problem is that there is no obvious context in which to place his geological activities: one has to start from scratch. Nineteenth-century English geology had its co-operative and competitive elements, whereby middle-class collectors and provincial men of science sought to establish a position for themselves in society by taking part in science (for examples, see Knell, 2000). This appears to have had parallels in Scotland (e.g. Andrews, 1982; Collie, 2003). Even in the nineteenth-century English geological hotspots of Scarborough and Bristol there was great variation in how individuals engaged morally and socially in scientific activities; but Miller's social context in Cromarty was very different from those English urban centres which were becoming the focus of the new science. Miller's well-known self-cultivation, with its inevitable implications for defining his identity, suggests that he 'should' be just such a conventionally competitive collector, as one might predict from the prevailing Calvinist work ethic; on the other hand, Miller's deep moral beliefs pull us into a completely different and possibly uncharted territory.

The third problem is that, in many ways, Miller is peripheral to conventional histories of science. Like many collectors, he risks being marginalized by his social status and geographical isolation, and the fact that his scientific achievement was (and largely still is) counted in specimens and sites rather than formal papers. Even when Miller had established himself as a geological writer, his invocation of God in so many debates, his posthumous association with the losing side in the struggle for acceptance of evolutionary thought, and his failure to write science in the increasingly formalized manner being adopted as the norm, have all tended to turn Miller into something of a Victorian curiosity to modern eyes. Yet Miller was courted by many of the great geologists of his day, few of whom, apparently, saw anything particularly odd in his perspective. In contrast, true biblical literalists, such as the Rev. George Young of Whitby, were castigated for their views even in the $1820 \mathrm{~s}$, when Miller's geologizing had scarcely begun. Miller himself had no time for biblical literalists, as is seen very clearly in Testimony of the Rocks, especially 'Lecture Tenth. The geology of the anti-geologists'. Arnold Bennett's 1910 novel Clayhanger also makes this distinction clear, when he describes the reception of Miller's work in the nonconformist Potteries of Staffordshire: 
[e]ven Hugh Miller's The Old Red Sandstone ..., then over thirty years old, was still being looked upon as dangerously original in the Five Towns in 1873. However, the effect of its disturbing geological evidence that the earth could scarcely have been begun and finished in a little under a week, was happily nullified by the suicide of its author; that pistol-shot had been a striking proof of the literal inspiration of the Bible (Bennett, 1954, p. 126).

There is plainly a serious anomaly in some - perhaps even all - modern perceptions of Miller and, although the introduction and many papers in Shortland (1996) went a long way towards addressing this, the issue remained open when a diverse group met in Cromarty to debate the man in the 2002 bicentenary conference (Borley, 2003). These tensions shall be considered through an analysis of Miller's collecting and his relationship to the fossil.

\section{THE DEVELOPMENT OF MILLER'S COLLECTING}

In what way was Miller any different from others who participated in science in provincial Britain in the second quarter of the nineteenth century? To imagine Hugh Miller on the foreshore collecting his fossils, or at home preparing, sorting and storing them, is to imagine a scene then common to the many fossil-rich areas on Britain's coasts (Knell, 2000). Geology in its various guises was an occupation taken up by labourer, self-improving artisan and middle-class 'philosopher'. Miller was, of course, successively all these things, but in this he was not unique: many others crossed these social boundaries. His uncles James and Sandy had nurtured the young Miller in local antiquarianism and natural history, but again this was commonly the means by which exceptional talent in natural history was developed - such sciences were not subjects of formal education. Nor was Miller's complex intertwining of geology, fossils and religion unique. The explosion of philosophical societies which acted as centres for the burgeoning science had in part been fuelled by a belief in unravelling the Divine plan. And while Miller's published writing is indeed distinctive for its nature, diversity and weight, a sample (those in Elgin Museum) of his unpublished letters to his friends suggests that, at least originally, he was a talented but still fairly typical provincial 'philosopher'. Around Elgin and elsewhere in Britain, collectors were racing to establish their scientific reputations through their discoveries. Miller was not totally detached from this race, but he saw other ways in which to deploy geology in his self-development. Miller stands out, in fact, not so much because of what he collected or how he did it - impressive as his achievements certainly are - but for what he made of what he collected.
An individual's attitudes to things, at least as material objects, change with time, almost by the minute. Miller was no different, but one can perhaps define four phases in his relationship with fossils (data from Miller's own books; Andrews, 1982; Oldroyd, 1996, and, for the 1840 date, local newspaper accounts, L. Borley, pers. comm., 2003):

- 1802-c. 1820. The period of his formal education such as it was - and his early self-education. Fossils entered his world sporadically but had no revolutionary effect.

- 1820-c. 1829. Miller's interest in fossils developed, particularly - so he tells us - after his finding of 'Liassic' (actually Upper Jurassic) fossils around Eathie on the shores of the Moray Firth.

- c. 1830-1837. Isolated from the wider culture of science, Miller was a 'Robinson Crusoe of geology', as he later put it (Miller, 1841, p. 125). In this phase, Miller made a serious study of the fossils of his home area, making his famous discovery of fossil fishes in the Old Red Sandstone at Cromarty in 1830, initially described only briefly in his first book, Scenes and Legends (1835), his account of the folklore and traditional history of Cromarty (in later editions the fossils were largely edited out; Paradis, 1996). Sporadically he read or heard about current geological ideas. But he could get relatively little useful specialist help and there were no 'practical men' essaying the local rocks for coal (Torrens, 2003). He remained for practical purposes out of contact with other collectors such as those in the Moray Firth area.

- 1837-1856. In 1837, Miller meets Patrick Duff and the Elgin geologists and - crucially - John Malcolmson, the East India Company doctor who had been drawn to Cromarty by mention of fossils in Scenes and Legends. Helped by Malcolmson, Miller progressively entered the broader cultural world of geology. The growth of his network was accelerated by his move to Edinburgh in 1840 to take up his position as Editor of The Witness. He also gained recognition (in his absence) at the meeting of the British Association for the Advancement of Science in Glasgow in 1840, which also widened his contacts amongst the scientific élite. Miller now had access to libraries and techniques such as thin sectioning, which would enable him to further his science (Hudson, 2003; Morrison-Low \& Nuttall, 2003).

\section{WHAT MILLER COLLECTED}

Miller's fossil collection started with his finds from the Upper Jurassic (to him, the Lower Jurassic 'Lias') and the Old Red Sandstone around his home town of Cromarty and neighbouring areas of the Black Isle and the Seaboard of Easter Ross to the north of the Cromarty Firth. To this Cromarty-centred core, from the start of 1840, Miller added material from around his new home city of Edinburgh (it is not clear how much he collected when working as a stonemason in 


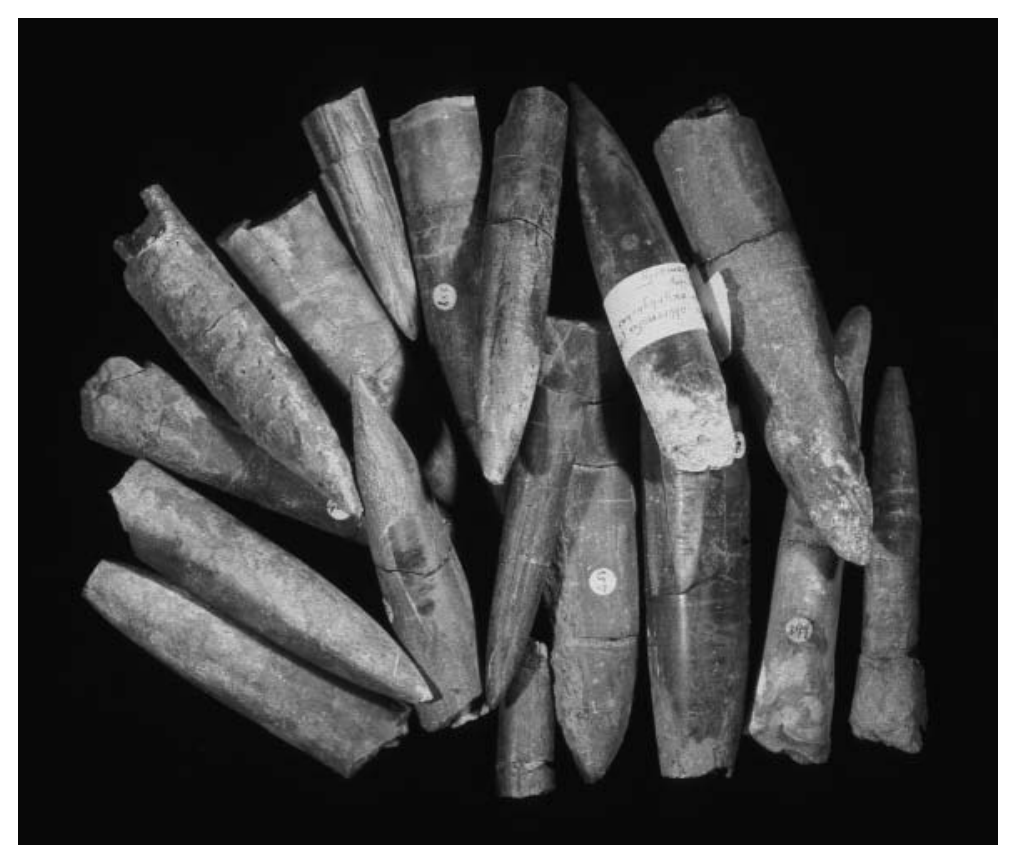

Fig. 3. Miller collecting in bulk: a sample of belemnites Pachyteuthis abbreviata (J. S. Miller, 1829) from the Jurassic of Easter Ross, mostly Shandwick, north of Cromarty, Hugh Miller collection, NMS G.1859.33 (pars). Photograph by Suzie Stevenson, copyright The Trustees of the National Museums of Scotland.

this area in the 1820s). With the publication of The Old Red Sandstone in 1841, Miller became a literary geological celebrity, and other collectors and geological literati made contact. His collection of fossils grew with the fruits of his summer or autumn vacation travels of a month or more, such as when he visited his boyhood friend the Rev. John Swanson on the 'Free Church Yacht Betsey' in the Inner Hebrides. Over the years, Miller cumulatively traversed Scotland from Aberdeen to Mull, and from Girvan to the Orkneys, and he notably collected on Eigg in 1844 and 1845 (Miller, 1858b; Hudson, 2003; Taylor, 2003). These travels were to have fuelled a major work on Scottish geology but this was never completed (Miller, 1858b, 1859). He also travelled into England to extend his knowledge, particularly of the older rocks, including a week at the newly classic Silurian locality of Wren's Nest at Dudley (Miller, 1847).

Miller's collection, as it is today preserved in the National Museums of Scotland, is striking in the way in which it reflects the truth of his writing. Miller was plainly not driven by the simple aesthetics that led some contemporaries to seek only perfect specimens. He collected in bulk and took specimens which other collectors would have rejected (Fig. 3; L. I. Anderson, pers. comm., 2002). This was almost inevitable given the nature of the deposits open to him, most fossils being incomplete and distorted (Janvier, 2003; Trewin, 2003). But far from rejecting them, he used them as complementary fragments - jigsaw pieces - to recreate a mental picture of the original animal, 'every new specimen that turned up furnishing a key for some part previously unknown - until at length, after many an abortive effort, the creatures rose up before me in their strange, unwonted proportions' (Fig. 4). Like others at the cutting edge of science, he found that he had no language with which to begin to understand these finds. So he simply distinguished his fossils with numbers for species (Miller, 1858a, pp. 527-528).

Miller's eye was sufficiently acute to appreciate both extremes of scale, from the grand landscape (Hudson, 2003) to the minute detail of fossils (Janvier, 2003; Morrison-Low \& Nuttall, 2003) and to make them work together. He recognized the need to train the eye and to construct a mental reference library of forms, a geological vocabulary of species. This analogy can be extended to the way in which Miller sought to work out the various ways in which fossils of the same species could be preserved, much as the same basic word can be inflected or parsed in many ways. Indeed, Miller's trip to Dudley was for this very purpose (Miller, 1847, p. 84).

As with other collectors, Miller's connoisseurship relied on the development of general taxonomic and stratigraphic notions of 'types' and 'series' to categorize observations and discriminate species and strata. Miller's respect for detail and for the value of even fragmentary fossils is also seen in the new breed of research-driven professional palaeontologist then emerging (Knell, 2000). 


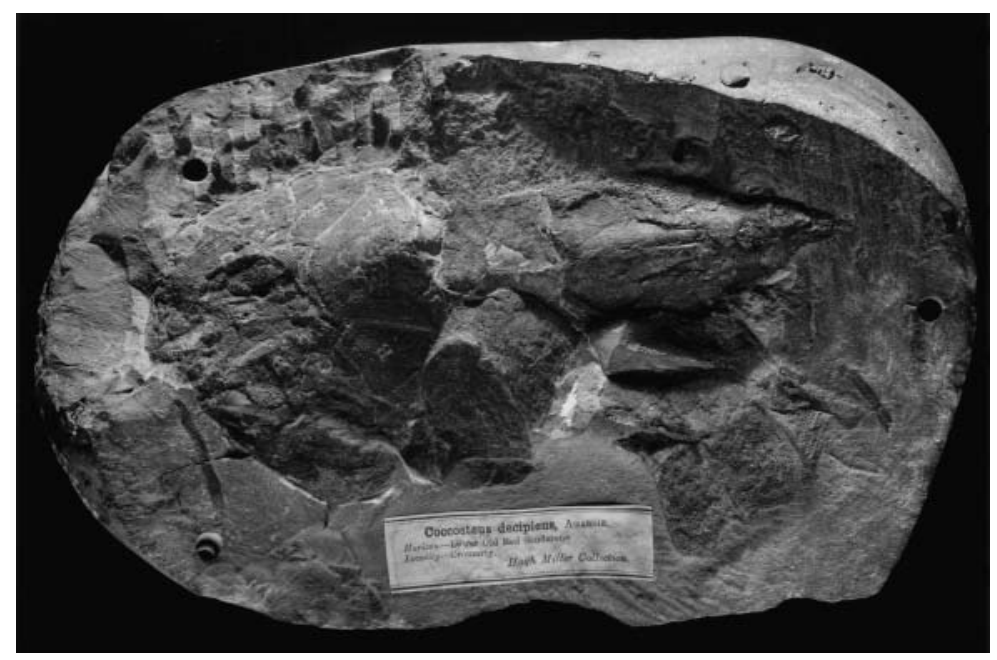

Fig. 4. Miller often tried to reconstruct the living animal from fragmentary specimens. This example of Coccosteus cuspidatus Miller 1841 ex Agassiz MS still shows the painted letters he used to label the individual elements (not to be confused with the numbers he initially used to distinguish species: see text). Old Red Sandstone, Cromarty, Hugh Miller collection, NMS.G.1859.33.1050. Photograph by NMS Photography Section, copyright The Trustees of the National Museums of Scotland.

\section{THE CROMARTY STONEMASON AS FOSSIL COLLECTOR}

One might well imagine that being a time-served stonemason had advantages for Miller the collector. He could hew open a nodule with ease, using the tools, skills and physique from a life of hard labour amidst rocks (Miller, 1858b, p. 241). But the best fossil collector need not be much of a geologist or much of a mason. Miller did not, as far as we know, and contrary to what is sometimes said, actually find fossils in the Black Isle quarries where he worked. More important was his presence on the same spot for a long time, enabling him to be opportunistic - for instance if a spring tide revealed a new exposure on a beach (Taylor, 2000). Like other collectors, Miller had to acquire an eye for the local strata and the signs that signal its fossils. Indeed, Miller illustrates the importance of developing what zoologists today call a 'search image', the ability to spot the very specific Gestalt of the fossils of a particular locality. His early collecting in the supposedly 'Liassic' rocks of Navity and Eathie gave him a particular eye for their fossiliferous nodules. When he came to draw up a model of local geology, he inferred the possible presence of the 'Lias' on the other side of the 'granitic gneiss' of the South Sutor headland, at Cromarty itself, and accordingly investigated the beach there. This research programme (as we might today describe it) led to his discovery of a stratum bearing nodules, which he promptly cracked open - no doubt prompted by his learning at Eathie to equate nodules with fossils (Miller, 1841, pp. 115-117; L. I. Anderson, pers. comm., 2002). This serendipitous misapplication of his 'search image' thus led him to the entirely different fossils of what became his classic beach site of The Old Red Sandstone fame, and the diversion of his 'research programme' towards the exploitation of this site and the search for more outcrops of fish-bearing Old Red in the area (Fig. 5; Miller, 1841, pp. 118-122; Oldroyd, 1996). However,

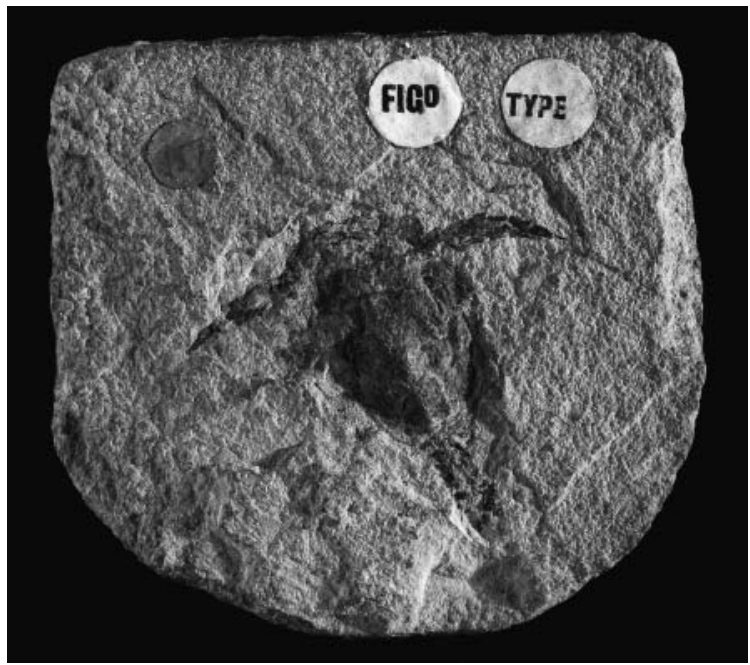

Fig. 5. Hugh Miller's iconic fossil. Lectotype specimen of Pterichthys milleri Miller 1841 ex Agassiz MS (now Pterichthyodes milleri (Miller 1841 ex Agassiz MS)). Old Red Sandstone, Cromarty, Hugh Miller collection, NMS.G.1859.33.5. Photograph by NMS Photography Section, copyright The Trustees of the National Museums of Scotland. 
Miller's accounts are - mostly - given with hindsight and, inevitably, leave much unsaid.

Being a local collector had real advantages but, at least before 1840, Miller had no other option. Sunday was his one clear day off in the working week, but he would have avoided collecting fossils on that day, certainly after his religious commitment of the mid1820 s, and probably before. Collecting was not a work of necessity or mercy, the only labour permitted on the Presbyterian Sabbath, and indeed Miller disapproved of even the temperate and self-improving country pursuits of the English Sunday (Miller, 1847, p. 42). As a stonemason, he at least had the winter months free for geological work, although they would have been limited by daylight and tide. Later, as a bank clerk, he found his travels restricted by his duties: 'I found myself somewhat in the circumstances of a tolerably lively beetle stuck on a pin, that, though able, with a little exertion, to spin round its centre, is yet wholly unable to quit it' (Miller, 1858a, p. 530). During this period, he could only go collecting on Saturday afternoons and during long summer evenings, when sometimes he and his wife Lydia would sail along the coast in their little boat to various localities, doubtless with a picnic, and often returning with freshly caught fish for supper (Miller, 1858a, pp. 532-533; Sutherland, 2002, pp. 49,170$)$. It was only from 1840 , at The Witness, that he seems to have found time for longer trips, partly for health reasons and partly to visit his Cromarty relatives.

\section{GEOLOGY BECOMES MORE THAN A COLLECTION}

During the early nineteenth century, careers in geology - if often precarious ones - were emerging in the more populous parts of Britain; but Miller had no such opportunities. From the start, geology was his recreation. His ambitions, his career hopes, were centred on literature. David Alston has kindly pointed out to us that Miller's general reputation as the local literary lion, the 'Cromarty Stonemason', prior to his departure from Cromarty, stemmed from his literary work, owing little if anything to geology (this is, of course, quite separate from his increasing reputation within the specialist geological community from the late 1830 s onwards).

Miller published no geological books until after his literary efforts had obtained him the editorship of The Witness at the start of 1840, apart from a brief discussion, mixed with topography and local history, in just two chapters of the first edition of Scenes and Legends in 1835. However, we cannot ascribe Miller's establishment as a geological writer solely to his becoming a newspaper editor. He had plainly already realized that his recreation could provide useful material for his journalistic repertoire: in 1838, he published a double article, 'Gropings of a Geologist', in Chambers's Edinburgh Journal (Miller, 1838). More- over, he told his friend Patrick Duff of his intentions to draw up an account of the geology of Cromarty over the summer of 1839 (Miller to Patrick Duff, 15 December 1838, Elgin Museum Geology Letter G1/2); so it is possible that much of The Old Red Sandstone was, in fact, written before he left his home town. Nevertheless, up to 1840 , Miller would have been regarded as no more than a minor collector in the culture of geology at that time.

Miller's editorial post gave him new opportunities for free time for fieldwork and for literary development (as the editor, he decided what went into the newspaper). The success of The Old Red Sandstone (1841, but serialized in The Witness in 1840) transformed matters. To his literary persona as historian and chronicler he added a new geological theme which cast him as having been a gifted 'Robinson Crusoe' of geology, and now an expert in fossil fish and in the interpretation of the deep past. His mix of geology with moral and social comment became his trademark. It introduced a new form of popular geological writing which, though rigorous, was often one or two steps removed from the technicalities then entering the standard popular works of Charles Lyell or Gideon Mantell (e. g. Lyell, 1830-1833; Mantell, 1844).

\section{MILLER AND THE POSSESSION OF NATURE}

Miller evidently took his collection seriously enough to build a 'museum' in the back garden of his house, Shrub Mount, in Portobello, Edinburgh, and he was grateful enough to accept Lord Kinnaird's gift of a mantrap (apparently of the 'humane' kind which lacked teeth) to protect it, even if his biographer, rather unreasonably, regarded this as an early symptom of the mental pressure which led Miller to suicide (Bayne, 1871, 2, p. 463). But what value was Miller protecting? Clearly the collection embodied a vast amount of hard work and time. Some might say that it also embodied an important part of his reputation. Yet there was certainly much more to it than a research resource, for it plainly had emotional value. Miller's writings are suffused with the thrill of discovery and the wonder and beauty of fossils, as well as rueful comments on the obsessive qualities of collecting (Fig. 6; e.g. Miller, 1858a, p. 160; 1858b, p. 433). Miller recognized that he had the morally beneficial attributes of the collector but he also appreciated that collecting had an emotive grip upon him.

Obsession, however, is nevertheless an unsatisfactory explanation in itself. Collectors of even the most mundane things are inevitably also making themselves, and constructing some aspect of their identities, whether intentionally or not. Perhaps there was a religious motive and, indeed, Miller has a reputation for invoking his Presbyterian God, although in fact such invocations are not actually that prominent in much of his writing. The obvious question is whether 


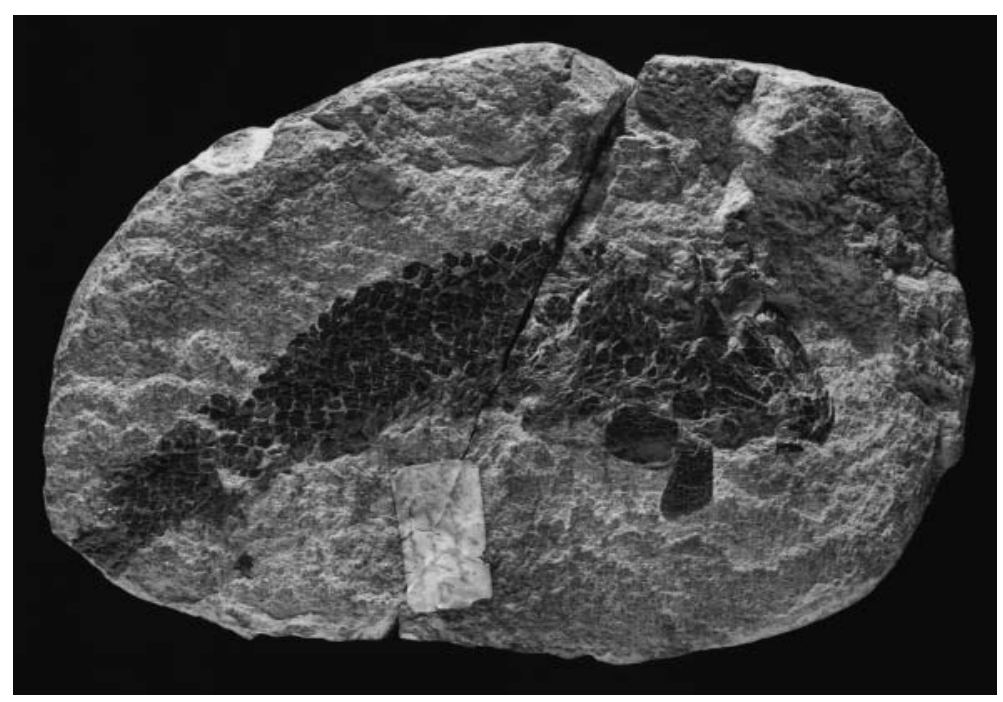

Fig. 6. Miller appreciated the beauty of fossils, such as the still glossy enamel on the scales of this fish. Osteolepis macrolepidotus Agassiz 1835, Old Red Sandstone, Cromarty, Hugh Miller collection, NMS.G.1859.33.1218. Photograph by NMS Photography Section, copyright The Trustees of the National Museums of Scotland.

his collecting was motivated by a religious drive to reveal the Divine plan of creation, which impelled so much effort at the time, and on which Miller wrote so eloquently, certainly in later life. However, Miller began collecting fossils at a time when he was wavering between religion and scepticism, a few years before he affirmed his adult commitment to Evangelical Presbyterianism around 1825 (Miller, 1858a, pp. 373-378). Rather, it seems likely that Miller was collecting primarily for his own personal satisfaction, for the pleasure of fresh air, discovery and intellectual and emotional achievement. The religious benefits, real as they became, were a later bonus.

Elsewhere in Britain, how people collected fossils, and took part in scientific activity, revealed core beliefs about the ownership of fossils, about the rights which this ownership was seen to confer, and about the control of the associated ideas (Knell, 2000). Miller's vigorous opposition to the Game Laws revealed his belief that the rights of private property should not be unreasonably absolute, particularly with regard to ownership of land. He believed that people had a right of access to the countryside and to the fruits of Nature wherever they might be found (Miller, 1862, pp. 243264; Taylor, 2003). When warned off geologizing on Eigg, Miller amused himself with the idea of a 'fossil preserve', linked with a 'great fossil act for the British empire, framed on the principles of the game-laws'. Nevertheless, he hit home with his pickaxe and extracted some fossil wood, 'feloniously, I dare say, though the crime has not yet got into the statute-book', jokingly hoping that the gentlemen of the Geological Society would rescue him should the case ever come to law (Miller, 1858b, p. 36).
At that time geology was especially dependent on the information being generated by the study of fossils, which was in turn driven forward by a general belief in the fossil collector's rights of ownership. Few people, after all, would collect fossils if they could not keep them. This was even truer of new fossils, of 'discoveries'. In Britain the social advantages of discovery in geology were well recognized. Like his contemporaries, Miller would fiercely protect his discoveries, though he at least sometimes justified this by emphasizing the work put into a fossil's study and reconstruction, possibly revealing the strength of his underlying Calvinism. His most notable defence came in a fierce priority dispute waged in public with a Mr Keir over the Old Red fish Pterichthys milleri (Andrews, 1982, p. 27). Miller, indeed, exemplified how one can 'own' both the physical fossil and the concepts abstracted from it when, in 1838, he joked with Patrick Duff about a possible crest carrying the image of Coccosteus and the motto 'Miller's own reptile', which was synonymous with 'The beast that Miller found' (Miller to Patrick Duff, 15 December 1838, Elgin Museum Geology Letter G1/2). Here, he was plainly aware of the significance of possessing an invention of one's own, whether in the sense of recognizing a new fossil animal, or that of the wider intellectual creation involved in its study and reconstruction.

\section{MILLER'S FOSSILS AS HISTORY AND LANDSCAPE}

We know little about the various possible collections to which Miller was exposed as a child (Miller, 1858a, 
1995). It is clear that books, then relatively scarce and precious, often appeared to him in the form of distinct collections to be discovered in the houses of relatives and neighbours. Their unwritten equivalents, the oral tales of the neighbourhood, were another kind of collection about which he tells us a great deal. He was clearly collecting stories and drawing upon them as a resource for his writing, as Miller's outstanding critic Mackenzie notes: 'gathering and pondering over the fossils of the mind even before those of the buried ages of the earth' (Mackenzie, 1905, p. 60).

Miller compared the Eathie fossils to an Alexandrian library (Miller 1858a, p. 163). If made, perhaps, with hindsight, it is still not a superficial simile, for the fossils provided a comparable resource for writing. Like books and oral traditions, the fossils provided a means to extend the imagined past back through time. They sat within a seamless historical continuum, which included also topography, legend, folk memory, surviving rural practices and the histories in books.

As Paradis (1996) shows, Miller's historical writing mythologized the past, drawing directly from traditional storytelling, with its controlled emphases and dramatic effects, its poetics and aesthetics. It also came to draw upon the theatre (O'Connor, 2003a, b). The autobiographical aspect of Miller's writings (Vincent, 1996) cast him as part of the myth, drawing not so much upon the hard reality of a life lived but rather upon the poetic reality of the great communicator in an equally poetic landscape (Mackenzie, 1905, p. 15). Miller was consistently true to his boyhood nickname of 'Sennachie', which originally meant - in Gaelic culture - a professional recorder and reciter of family history, but also has the more general meaning, which probably applies here, of a teller of traditional tales. Mackenzie deployed another traditional if, perhaps, more Lowlander term, makar - the archaic Scots for poet - when he called Miller 'a "makar" in geology; a reconstructor in his own melodious and strikingly suggestive language of ideal geologic landscapes' (Mackenzie, 1905, pp. 121-122).

Miller frequently referred to one of his idols, the poet William Cowper, in First Impressions of England. A visit to Cowper's home town of Olney led Miller to quote him (Miller, 1847, p. 260):

\section{Now roves the eye;}

And, posted on this speculative height,

Exults in its command. The sheepfold here

Pours out its fleecy tenants o'er the glebe.

At first, progressive as a stream, they seek

The middle field; but, scattered by degrees,

Each to his choice, soon whiten all the land ...

The poet's eye had perceived what others do not see: imagination is replaced by perceptiveness rooted in the observation of reality that was so important to Miller's world view (and, indeed, Miller wrote little fiction). Miller never really achieved that level of concision and he had to make a rather more substantial effort to get his sheep out of the fold, or, at least in this case, extract his saurian from the footprints and other traces on a stone slab in Warwick Museum (Miller, 1847, p. 191; chelonians comprise turtles, terrapins and tortoises):

The chelonian journeyed adown a moist sandy slope, furrowed by ripple-markings, apparently to a watering-place. He travelled leisurely, as became a reptile of consequence, set down his full weight each step he took, and left a deep-marked track in double line behind him. And yet, were his nerves less strong, he might have bestirred himself; for the southern heavens were dark with tempest at the time, and a thunderous-like shower, scarce a mile away, threatened to wet him to the skin. On it came; and the large round drops, driven aslant by a gale from the south, struck into the sand like small shot, at an angle of sixty. How the traveller fared on the occasion has not transpired; but clear and palpable it is that he must have been a firm fellow, and that the heavy globular drops made a much less marked impression on the sand consolidated by his tread than when they fell elsewhere on the incoherent surface around him.

But the observation and precision are there, also. Miller is here deploying a linguistic invention that resembles Cowper's. It succeeds because it draws upon the observed world and upon things which we could see and yet fail to see - at least until the author delivers the narrative which, though evocative, becomes all the more sublime for being rooted in reality.

A key to this interpretation of the object is the presence of Miller himself, juxtaposed with the fossil world which he is interpreting. Sometimes he seems to be Virgil, perhaps escorting the reader's Dante through an imagined Palaeozoic Inferno or Paradise. At other times he is more like the visitor's guide then still common in museums. Miller's explicit guidance, and his return sooner or later to the specimen or site where he himself is situated as observer, help the reader travel through time from deep past to present, and relate the two (Fig. 7). Whether he is making social comment or showing us a fossil specimen, Miller's presence is not merely autobiographical: it has powerful heuristic and literary functions, like the presence of each specimen itself as a piece of reality, simultaneously both of the past and the present.

As Miller moved from dealing with observations on life and the past, which used fossils as real-world reference points and libraries of evidence, to wider issues of the place of God in creation and the truths of geology, his fossils took on new roles as reifications: things which made concrete the truth of his beliefs. In Footprints of the Creator (1849), Miller attempted to kill off the reheated Lamarckian evolutionism of Robert Chambers's Vestiges of the Natural History of Creation (1844). It is striking how he used his specimens like chessmen, or the specialist troops of an army: recognizably individual specimens were 


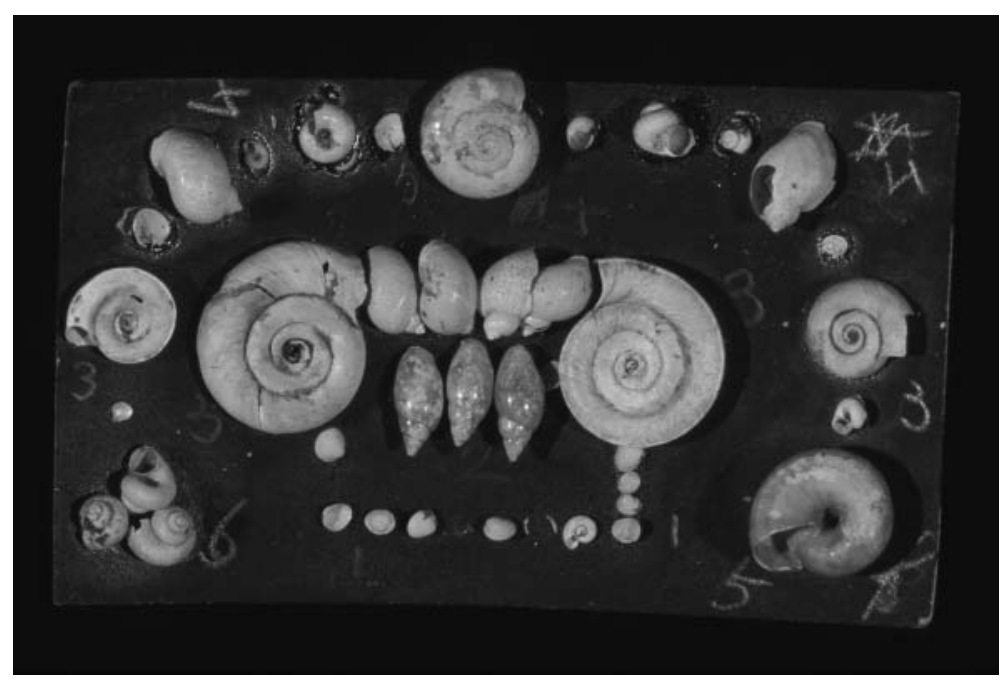

Fig. 7. Miller cemented these fossil freshwater shells from the former Boroughloch of Edinburgh onto a card in the form of an Ionic column capital. Miller reconstructed the past from specimens such as these (Miller, 1862). He took a great interest in what would now be called Quaternary geology, prominent in the neighbourhood of his successive homes of Cromarty and Edinburgh. Gastropods from postglacial lake deposits, the Meadows, Edinburgh, Hugh Miller Collection, NMS.G.1859.33.5011. Photograph by Suzie Stevenson, copyright The Trustees of the National Museums of Scotland.

deployed in sequence, thumped down on the table as his assault proceeded. For instance, Miller's initial breakthrough was made with his narrative of the finding of a particular example of the fossil fish 'Asterolepis', precisely located at a specific time and place in the Orcadian landscape near Stromness (Miller, 1864, pp. 5-8, and cf. Miller, 1858b; Taylor, 2003).

In Footprints and in Testimony of the Rocks Miller clearly trod a borderline between the Biblical literalists and those geologists and materialists who saw no role for God. Here, again, Miller found his own way, marrying evidence with belief. He was not engaged in compromise but in searching for a solution to the puzzle which accommodated two sets of unquestionable truths (Miller, 1857, p. 265; Macleod, 1996, 2002; O'Connor, 2003a). As he put it, 'Between the Word and the Works of God there can be no actual discrepancies ...' and again

[given that] the Scriptures could not possibly have been given to us as revelations of scientific truth, seeing that a single scientific truth they never yet revealed, and ... it must be in vain to seek in science those truths which lead to salvation, seeing that in science these truths were never yet found, there would be little danger even of difference among them, and none of collision.

This is not a man torn between science and religion, but, on the contrary, one who is comfortable with both. There is little if any evidence that Miller's contemporaries found him far out of line. Many contemporary geologists were in the same position of accommodating their Christianity with their geology, while, for its own part, the Free Church, at least, felt the need to provide geological courses at its College for trainee ministers (Andrews, 1982).

\section{MILLER'S FOSSILS AND THEIR IMPORTANCE}

After his early death, Miller's widow received two offers for his collection: one of $£ 1000$ from 'a Scottish Nobleman' and another of 1000 guineas [£1050] from an American college. The British government was willing to put up $£ 500$ and a committee under the direction of the Lord Provost of Edinburgh successfully organized a subscription to meet the shortfall, saving the collection 'for Scotland', as the Proposal to purchase the museum of the late Hugh Miller put it (Anon., [1858]; Taylor \& Gostwick, 2003). The precursor of what is now the National Museums of Scotland formally took possession of the collection in 1859 . Some other Miller specimens exist elsewhere, including those in Miller House in Cromarty. Miller's son, Hugh (1850-1896), became a professional geologist with the Geological Survey in nice contrast to his father, and the specimens there presumably stem from the 'museum' which he set up in his father's memory, apparently some time after 1884 , during the period when he was mapping his father's old stamping grounds for the Geological Survey (Gunn, 1897; Horne, [1899]).

This appraisal has revealed further depths to Hugh Miller's appreciation of geological specimens and to the significance of his surviving collection. Miller's relationship with the material world of objects showed 
remarkable consistency and an unwillingness to compartmentalize. They give no indication of a man torn between opposites. His fossils performed, and continue to perform, real scientific service. Yet, on top of this, Miller gave his fossils the role of reconciling geological and religious truths and deployed them in a pragmatism that drew upon both ends of the scale. The fossils also provided a link in the continuum of time. They comprised a vehicle for exploring the deep past without losing continuity with a past of recorded folk legend and history, and a present where he was situated as observer, geologist, stonemason and 'Sennachie'. The fossils also provided evidence of a reality that could be explored scientifically and poetically, without the two coming into conflict. Miller's fossils sat as subjects for his painterly prose, perhaps in individual portraits, or as part of landscapes, or just studied in minute detail there was no constraint on scale or resolution. Miller's fossils exemplify the deep continuity of his world. Attempting to compartmentalize it is like cutting quicksilver. Whatever perspective he takes, whatever analytical criterion is used, Miller's work is unsegmented, often leading us back to consider the impact of Cromarty, and of being a Lowlander and a Calvinist.

\section{ACKNOWLEDGEMENTS}

The authors are very grateful to Lester Borley and the Cromarty Arts Trust for permission to reprint this, with emendations, updating and the addition of an introductory section and illustrations, from Knell \& Taylor (2003). John Hudson, Alison Morrison-Low,
Ralph O'Connor, Bob Nuttall and Hugh Torrens are thanked for early sight of their papers in Borley (2003) and for discussion.

Amongst the many colleagues to whom the authors are indebted are especially David Alston for comments on Miller's local reputation; Lyall Anderson for insights into Miller's inclusive collecting, including fragmentary fossils, and the significance of the nodules at Eathie, and for discussion of Black Isle geology; Susan Bennett, David Addison and the Moray Society for assistance and permission to cite the Miller letters in Elgin Museum; Lester Borley for the date of Miller's departure to Edinburgh; John Burnett for the Clayhanger reference, also noted by Harvie (2003), and explaining 'humane' mantraps; Godfrey Evans on the statue; Graham McKenna for locating the so far unique copy of the Proposal to purchase the museum of the late Hugh Miller in the British Geological Survey archives; and the staff of the National Museums of Scotland Library for their assistance.

\section{Note added in proof}

We draw attention to two new papers which throw significant further light on Hugh Miller's fossil collecting activities, but which have appeared too late for us to discuss properly. Anderson (2005) assesses Miller's palaeobotanical work, notably the practicalities of fieldwork at the sites in question. Campbell and Holder (2005) analyse the standing evidence and archival records for Miller's last house, Shrub Mount in Portobello (now in Edinburgh) and locate his specially erected 'museum'.

\section{REFERENCES}

Agassiz, J.L.R. 1835. On the fossil fishes of Scotland. Annual Report of the British Association for the Advancement of Science, Edinburgh, 1834, 646-649.

Alston, D. 1996. The fallen meteor: Hugh Miller and local tradition. In (Shortland, M.; ed.) Hugh Miller and the controversies of Victorian science. Oxford University Press, Oxford, 206-229.

Anderson, L.I. 2005. Hugh Miller: introducing palaeobotany to a wider audience. In (Bowden, A.J., Burek, C.V. \& Wilding, R.; eds) History of Palaeobotany. Selected Essays. Geological Society, London, Special Publications, 241, 63-90.

Andrews, S.M. 1982. The discovery of fossil fishes in Scotland up to 1845 with checklists of Agassiz's figured specimens. Royal Scottish Museum, Edinburgh.

Anon. [1858]. Proposal to purchase the museum of the late Hugh Miller. 4pp pamphlet. Only known copy is Item 1/669 in the British Geological Survey, Keyworth, Library Archives; see Taylor \& Gostwick (2003) for dating.

Baile de Laperrière, C. (ed.) 1991. The Royal Scottish Academy exhibitors 1826-1990. A dictionary of artists and their work in the Annual Exhibitions of The Royal Scottish Academy. Hilmarton Manor Press, Calne.

Bayne, P. 1871. The life and letters of Hugh Miller. 2 vols. Strahan \& Co., London.

Bennett, A. 1954. Clayhanger. [originally published 1910]. Penguin, Harmondsworth.
Borley, L. (ed.) 2002. Hugh Miller in context: geologist and naturalist: writer and folklorist. A collection of papers presented at two conferences The Cromarty Years (2000) and The Edinburgh Years (2001). Cromarty Arts Trust, Cromarty.

Borley, L. (ed.) 2003. Celebrating the life and times of Hugh Miller. Scotland in the early 19 th century, ethnography and folklore, geology and natural history, church and society. Cromarty Arts Trust, Cromarty, and Elphinstone Institute of the University of Aberdeen, Aberdeen.

Campbell, I. \& Holder, J. 2005. Hugh Miller's other house: the enigma of Shrub Mount. Architectural Heritage, 16, $51-71$.

[Chambers, R.] 1844. Vestiges of the Natural History of Creation and other writings. [reprinted 1994 with introduction, etc., by J. A. Secord]. University of Chicago Press, Chicago.

Collie, M. 2003. Hugh Miller's dealings with contemporary scientists. In (Borley, L.; ed.) Celebrating the life and times of Hugh Miller. Scotland in the early 19th century, ethnography and folklore, geology and natural history, church and society. Cromarty Arts Trust, Cromarty, and Elphinstone Institute of the University of Aberdeen, Aberdeen, 227-236.

Gostwick, M. 2004. Homage to a poet of geology. Earth Heritage, 22, 24-25.

Gunn, W. 1897. Obituary notice of Hugh Miller, F.R.S.E., F.G.S., etc., of H.M. Geological Survey of Scotland. History of the Berwickshire Naturalists' Club, 15, 322-324. 
Harvie, C. 2003. Hugh Miller and the Scottish crisis. In (Borley, L.; ed.) Celebrating the life and times of Hugh Miller. Scotland in the early 19th century, ethnography and folklore, geology and natural history, church and society. Cromarty Arts Trust, Cromarty, and Elphinstone Institute of the University of Aberdeen, Aberdeen, 34-47.

Horne, J. [1899]. Obituary notice of Hugh Miller. Transactions of the Edinburgh Geological Society, 7, 132-138.

Hudson, J.D. 2003. Hugh Miller's geological discoveries and observations on the Isle of Eigg, as recorded in 'The Cruise of the Betsey' and in the light of modern knowledge. In (Borley, L.; ed.) Celebrating the life and times of Hugh Miller. Scotland in the early 19th century, ethnography and folklore, geology and natural history, church and society. Cromarty Arts Trust, Cromarty, and Elphinstone Institute of the University of Aberdeen, 197-213.

Janvier, P. 2003. Armoured fish from deep time: from Hugh Miller's insights to current questions of early vertebrate evolution. In (Borley, L.; ed.) Celebrating the life and times of Hugh Miller. Scotland in the early 19th century, ethnography and folklore, geology and natural history, church and society. Cromarty Arts Trust, Cromarty, and Elphinstone Institute of the University of Aberdeen, Aberdeen, 177-196.

Knell, S.J. 2000. The culture of English geology, 1815-1851. Ashgate, Aldershot.

Knell, S.J. \& Taylor, M.A. 2003. Hugh Miller, fossil discoverer and collector. In (Borley, L.; ed.) Celebrating the life and times of Hugh Miller. Scotland in the early 19th century, ethnography and folklore, geology and natural history, church and society. Cromarty Arts Trust, Cromarty, and Elphinstone Institute of the University of Aberdeen, Aberdeen, 156-167.

Lowenthal, D. 2003. Caring for nature: the transatlantic canvas of the nineteenth century. In (Borley, L.; ed.) Celebrating the life and times of Hugh Miller. Scotland in the early 19th century, ethnography and folklore, geology and natural history, church and society. Cromarty Arts Trust, Cromarty, and Elphinstone Institute of the University of Aberdeen, Aberdeen, 14-33.

Lyell, C. 1830-1833. Principles of Geology. Murray, London.

Mackenzie, W.M. 1905. Hugh Miller. A critical study. Hodder and Stoughton, London.

Mackenzie, W.M. (ed.) 1908. Selections from the writings of Hugh Miller. Alexander Gardner, Paisley.

Macleod, D. 1996. Hugh Miller, the Disruption, and the Free Church of Scotland. In (Shortland, M.; ed.) Hugh Miller and the controversies of Victorian science. Oxford University Press, Oxford, 187-205.

Macleod, D. 2002. Set in stone. Life and Work: the magazine of the Church of Scotland, February, 20-21.

Mantell, G.A. 1844. The Medals of Creation; or, First Lessons in Geology, and in the study of Organic Remains. 2 vols. Bohn, London.

Miller, H. 1835. Scenes and Legends of the North of Scotland; or, The Traditional History of Cromarty. Black, Edinburgh [revised 1850 edition reprinted 1994 with introduction and notes by J. Robertson, B\&W Publishing, Edinburgh].

Miller, H. 1838. Gropings of a working man in geology. Chambers's Edinburgh Journal, 28 April, 109-110, and 26 May, 137-139 [reprinted in Miller, 1995, pp. 246-257].

Miller, H. 1841. The Old Red Sandstone, or, New walks in an old field (1st edn). John Johnstone, Edinburgh.

Miller, H. 1847. First impressions of England and its people (1st edn). John Johnstone, London.
Miller, H. 1849. Footprints of the Creator or, the Asterolepis of Stromness. Johnstone and Hunter, London.

Miller, H. 1857. The Testimony of the Rocks, or, Geology in its bearings on the two theologies, natural and revealed (1st edn). [reprinted 2001 with introductions by P. Foster and M. A. Taylor, St Matthew Publishing, Cambridge].

Miller, H. 1858a. My Schools and Schoolmasters or The story of my education. Constable, Edinburgh [reprinted 1993 with introduction and notes by J. Robertson, B\&W Publishing, Edinburgh]

Miller, H. 1858b. The Cruise of the Betsey,... with, Rambles of a Geologist.... Constable, Edinburgh [reprinted 2003 with introduction and notes by M. A. Taylor, National Museums of Scotland Publishing, Edinburgh].

Miller, H. 1859. Sketch-book of Popular Geology (1st edn). Constable, Edinburgh.

Miller, H. 1862. Essays, historical and biographical, political and social, literary and scientific (1st edn). A. \& C. Black, Edinburgh; Hamilton, Adams \& Co., London.

Miller, H. 1891 [first published 1864]. Edinburgh and its neighbourhood, geological and historical; with the geology of the Bass Rock. Nimmo, Hay \& Mitchell, Edinburgh.

Miller, H. 1995. Hugh Miller's Memoir. (M. Shortland; ed.). Edinburgh University Press, Edinburgh.

Miller, J.S. 1829. Observations on belemnites. Transactions of the Geological Society of London, 2, 45-62.

Morrison-Low, A.D. \& Nuttall, R.H. 2003. Hugh Miller in an age of microscopy. In (Borley, L.; ed.) Celebrating the life and times of Hugh Miller. Scotland in the early 19th century, ethnography and folklore, geology and natural history, church and society. Cromarty Arts Trust, Cromarty, and Elphinstone Institute of the University of Aberdeen, Aberdeen, 214-226.

O'Connor, R. 2003a. Hugh Miller and geological spectacle. In (Borley, L.; ed.) Celebrating the life and times of Hugh Miller. Scotland in the early 19th century, ethnography and folklore, geology and natural history, church and society. Cromarty Arts Trust, Cromarty, and Elphinstone Institute of the University of Aberdeen, Aberdeen, 237-258.

O'Connor, R. 2003b. Thomas Hawkins and geological spectacle. Proceedings of the Geologists' Association, 114, 227-241

Oldroyd, D.R. 1996. The geologist from Cromarty. In (Shortland, M.; ed.) Hugh Miller and the controversies of Victorian science. Oxford University Press, Oxford, 76-121.

Paradis, J.G. 1996. The natural historian as antiquary of the world: Hugh Miller and the rise of literary natural history. In (Shortland, M.; ed.) Hugh Miller and the controversies of Victorian science. Oxford University Press, Oxford, $122-150$.

Robb, D. 1996. 'Stand, and unfold yourself': My Schools and Schoolmasters. In (Shortland, M.; ed.) Hugh Miller and the controversies of Victorian science. Oxford University Press, Oxford, 246-264.

Robertson, J. 2002. Scenes and legends of the north: feeding a youthful imagination. In (Borley, L.; ed.) Hugh Miller in context: geologist and naturalist: writer and folklorist. A collection of papers presented at two conferences The Cromarty Years (2000) and The Edinburgh Years (2001). Cromarty Arts Trust, Cromarty, 17-25.

Secord, J.A. 2000. Victorian sensation. The extraordinary publication, reception, and secret authorship of Vestiges of the Natural History of Creation. University of Chicago Press, Chicago.

Secord, J.A. 2003. From Miller to the Millennium. In (Borley, L.; ed.) Celebrating the life and times of Hugh Miller. 
Scotland in the early 19th century, ethnography and folklore, geology and natural history, church and society. Cromarty Arts Trust, Cromarty, and Elphinstone Institute of the University of Aberdeen, Aberdeen, 328-337.

Shortland, M. (ed.) 1996. Hugh Miller and the controversies of Victorian science. Oxford University Press, Oxford.

Stevenson, S. 2002. The personal art of David Octavius Hill. Yale University Press, New Haven.

Sutherland, E. 2002. Lydia, wife of Hugh Miller of Cromarty. Tuckwell, East Linton.

Taylor, M.A. 2000. Mary Anning, Thomas Hawkins and Hugh Miller, and the realities of being a provincial fossil collector. Edinburgh Geologist, 34, 28-37.

Taylor, M.A. 2002a. Fellow Scots: John Muir and Hugh Miller. John Muir Trust Journal and News, 32, 12-17, 68-69; also on www.jmt.org.

Taylor, M.A. 2002b. Man of Vestiges - Robert Chambers 200 years on. Edinburgh Geologist, 39, 32-35; also on www.edinburghgeolsoc.org.

Taylor, M.A. 2002c. Review Symposium: Vestigial sensations [essay review of J. A. Secord, Victorian sensation]. Metascience, 11 [for 2001] (1), 4-10.

Taylor, M.A. 2003. [Introduction, notes, and glossary, etc., to facsimile reprint edition of Hugh Miller (1858) The Cruise of the Betsey, with, Rambles of a Geologist]. National Museums of Scotland Publishing, Edinburgh.

Taylor, M.A. \& Gostwick, M. 2003. Hugh Miller's collection - a memorial to a great geological Scot. Edinburgh Geologist, 40, 24-29; also on www.edinburghgeolsoc.org.

Torrens, H.S. 1998. Geology and the natural sciences: some contributions to archaeology in Britain 1780-1850. In (Brand, V.; ed.) The study of the past in the Victorian Age. Oxbow Monograph, 73. Oxbow Books, Oxford, 35-59.
Torrens, H.S. 2003. William Smith (1769-1839) and the search for English raw materials: some parallels with Hugh Miller and Scotland. In (Borley, L.; ed.) Celebrating the life and times of Hugh Miller. Scotland in the early 19th century, ethnography and folklore, geology and natural history, church and society. Cromarty Arts Trust, Cromarty, and Elphinstone Institute of the University of Aberdeen, Aberdeen, 137-155.

Trewin, N.H. 2003. Hugh Miller's fish: the 'winged Pterichthys'. In (Borley, L.; ed.) Celebrating the life and times of Hugh Miller. Scotland in the early 19th century, ethnography and folklore, geology and natural history, church and society. Cromarty Arts Trust, Cromarty, and Elphinstone Institute of the University of Aberdeen, Aberdeen, 168-176.

Vincent, D. 1996. Miller's improvement: a classic tale of self-advancement? In (Shortland, M.; ed.) Hugh Miller and the controversies of Victorian science. Oxford University Press, Oxford, 230-245.

Waterston, C.D. 2002a. Hugh Miller as a geologist and naturalist. In (Borley, L.; ed.) Hugh Miller in context: geologist and naturalist: writer and folklorist. A collection of papers presented at two conferences The Cromarty Years (2000) and The Edinburgh Years (2001). Cromarty Arts Trust, Cromarty, 26-31.

Waterston, C.D. 2002b. An awakening interest in geology. In (Borley, L.; ed.) Hugh Miller in context: geologist and naturalist: writer and folklorist. A collection of papers presented at two conferences The Cromarty Years (2000) and The Edinburgh Years (2001). Cromarty Arts Trust, Cromarty, 85-91.

Woodward, H. 1918. Obituary, George Jennings Hinde, Ph. D. (Munich), F.R.S., F.G.S., V.P.Pal.Soc. Geological Magazine, (6)5, 233-240.

Manuscript received 20 September 2004; revised typescript accepted 6 June 2005 